\title{
Implementasi Softroare Aplikasi Siadikdasmen Pada SMA Muhammadiyah 3 Yogyakarta
}

\author{
Ahim Abdurahim1, Sigit Arie Wibowo² \\ ${ }^{1,2}$ Program Studi Akuntansi, Fakultas ekonomi dan Bisnis, Universitas Muhammadiyah Yogyakarta \\ Email: ahim@umy,ac.id, ahimabdurahim@gmail.com \\ DOI: $10.18196 / p p m .31 .147$
}

\begin{abstract}
Abstrak
Kegiatan Pengabdian kepada Masyarakat (PkM) bertujuan membantu SMA Muhammadiyah 3 Kota Yogyakarta, menyusun laporan keuangan yang andal, realtime dan diakses darimanapun menggunakan software aplikasi Siadikdasmen. Kegiatan ini sangat penting mengingat Peraturan Pemerintah nomor 24 tahun 2018 mengharuskan sekolah memiliki Nomor Induk Berusaha (NIB). Untuk memperoleh NIB sekolah harus memiliki NPWP. Konsekuensi memiliki NPWP adalah menyampaikan laporan keuangan. Pelaksanaan PkM dilakukan 8 tahap. Hasil kegiatan adalah software untuk mengolah data keuangan dengan mudah dan informasi keuangan realtime. Simpulannya software sangat membantu manajemen sekolah dalam menyusun dan menyajikan informasi keuangan bagi manajemen dan bagi orangtua wali siswa.
\end{abstract}

Kata Kunci: Software, siadikdasmen, SMK Muhammadiyah, laporan keuangan, NIB

\section{Pendahuluan}

Mengacu kepada Peraturan pemerintah nomor 24 tahun 2018 (KemenkumHam, 2018), bahwa setiap pelaku usaha wajib memiliki Nomor Induk Berusaha (NIB) dan untuk memperoleh NIB pelaku usaha wajib memiliki NPWP dan Akte Pendirian Yayayan. Untuk memperoleh NIB harus memiliki NPWP dan akte pendirian yayasan. Konsekuensi dari kepemilikan NPWP adalah sekolah harus menyampaikan Laporan Keuangan setiap tahunnya kepada KPP. Kebutuhan internal terhadap sistem informasi yang cepat dan akurat tidak hanya untuk memenuhi kebutuhan perpajakan. Secara internal manajemen sekolah membutuhkan informasi digital yang cepat dan akurat untuk pengambilan keputusan dan serta penyebaran informasi kepada Siswa terkait administrasi keuangannya.

Untuk membantu kedua permasalahan tersebut tim PkM FEB UMY mengusulkan kegiatan implementasi Siadikdasmen. Kegiatan PkM ini diharapkan dapat membantu sekolah dalam menyusun laporan keuangan berbasis web sehingga dapat membantu sekolah dalam menyusun laporan keuangan dengan cepat, akuran dan realtime (Rachmawati \& Nurjanah, 2017) serta membantu menyediakan informasi yang dapat diakses dengan mudah oleh para stakeholders lainnya (Waspodo, 2014).

\section{Metode Pelaksanaan}

Kegiatan PkM implementasi software aplikasi SIADIKDASMEN dilakukan dengan tahapan berikut:

1. Survei prosedur pengelolaan keuangan sekolah.

2. Survei kebijakan keuangan sekolah Yogyakarta

3. Survei dan diskusi kebutuhan output pelaporan keuangan sekolah.

4. Survei struktur organisasi dan kewenangan yang berkaitan dengan pengelolaan keuangan sekolah

5. Merancang kode rekening, kode mata anggaran kode akses.

6. Merancang draft awal software aplikasi Siadikdasmen sekolah

7. Melakukan pengujian software aplikasi Siadikdasmen dengan data simulasi.

8. Melakukan entry data-data master dan mengevaluasi kesesuaiannya.

9. Melakukan entry data transaksi dengan menggunakan data asli sekolah

10. Melakukan evaluasi hasil proses keseluruhan 
Pertimbangan pemilihan SMA Muhammadiyah 3 sebagai situs kegiatan PkM karena sekolah tersebut sebelumnya telah menggunakan Siadikdasmen berbasis desktop, dan berkeinginan untuk mengembangkan menjadi berbasis website. Tim PkM bekerjasama dengan programmer dari CV. Orbita sebagai mitra untuk mengembangkan software. Software aplikasi Siadikdasmen dirancang menggunakan bahasa pemrograman PHP dan menggunakan data base My Sql. Data base disimpan dalam server milik Pimpinan Pusat Muhammadiyah. Sekolah dapat mengakses software aplikasi Siadikdasmen melalui url:siadikdasme.mugaygy.or.id.

\section{Hasil dan Pembahasan}

Tim PkM sangat membutuhkan partisipasi mitra untuk menunjang keberhasilan implementasi software aplikasi Siadikdasmen (Budiman \& Arza, 2013; Putra \& Alfian, 2016) dalam bentuk:

1. Komitmen Pimpinan sekolah dalam bentuk surat tertulis untuk mengimplementasikan software aplikasi Siadikdasmen

2. Dukungan pimpinan dan staf sekolah dalam memberikan informasi terkait prosedur pengelolaan keuangan, pengaturan kesiswaan yang berkaitan dengan keuangan, kebijakan keuangan serta informasi struktur organisasi yang berwenang dalam pengelolaan keuangan.

3. Dukungan pimpinan dan staf sekolah memberikan informasi mengenai laporan keuangan yang dibutuhkan dan daftar kegiatan yang dilakukan serta format, bentuk dan isi laporan keuangan dan kegiatan yang dibutuhkan oleh sekolah

4. Dukungan pimpinan dan staf sekolah memberikan akses kepada tim untuk memperoleh dokumen laporan keuangan, bukti transaksi, dokumen kebijakan dan catatan-catatan yang diperlukan untuk merancang software aplikasi Siadikdasmen.

5. Keterlibatan staf keuangan sekolah bersama asisten dalam melakukan proses transaksi menggunakan data asli dan membantu memberikan informasi jika terjadi adanya kesalahan atau ketidak sesuaian data sehingga data laporan yang dihasilkan belum akurat.

6. Keterlibatan pimpinan dan staf sekolah dalam membantu memberikan penilaian apakah software aplikasi Siadikdasmen yang dihasilkan dan dan palporan yang dihasilkan sudah memenuhi atau masih ada kekuarangan.

\section{Simpulan}

Dukungan pimpinan dan keterlibatan staf sangat berpengaruh dalam keberhasilan perancangan dan implementasi Siadikdasmen. Kebutuhan utama sekolah adalah laporan posisi kekayaan, laporan aktifitas dan laporan arus kas serta informasi pembayaran siswa. Kepala sekolah dan bendahara secara rutin membutuhkan informasi posisi kas dan mutasi kas, sedangkan staf SPP dan wali siswa membutuhkan informasi posisi pembayaran siswa, dengan demikian software aplikasi Siadikdasmen sangat bermanfaat bagi sekolah maupun wali siswa

\section{Ucapan Terima Kasih}

Ucapan terima kasih kami sampaikan kepada LP3M UMY, yang telah memberikan pendampingan dan pendanaan kegiatan. Ucapan terima kasih kami sampaikan kepada Bapak Herynugroho,MPd (kepala Sekolah SMA Muhammadiyah 3 Yogyakarta), Mbak Tri Yuniati (bendahara sekolah) dan mas Duwi Paryanto (staf pembayaran SPP) yang telah menerima dan membantu implementasi siadikdasmen. Ucapan terimakasih kami sampaikan kepada LPPK Pimpinan Pusat Muhammadiyah dan CV. Orbita yang telah ikut mendukung perencanaan dan pelaksanaan implementasi siadikdasmen. 


\section{Daftar Pustaka}

Budiman, F., \& Arza, F. I. (2013). Pendekatan Technology Acceptance Model dalam Kesuksesan Implementasi Sistem Informasi Manajamen Daerah. Wahana Riset Akuntansi, 1(1).

Peraturan Pemerintah Repblik Indonesia nomr 24 tahun 2018 tentang Pelayanan Perizinan Berusaha Terintegrasi Secara Elektronik, (2018).

Putra, W. M., \& Alfian, M. (2016). Pengujian Kesuksesan Implementasi Sistem Informasi Akuntansi Lembaga Keuangan Mikro: Modified Delone Mcleon Model. Journal of Accounting and Investment, 17(1), 53-65.

Rachmawati, S., \& Nurjanah, N. (2017). Implementasi Data Keuangan dengan Zahir Accounting pada PT. Anugrah Analisis Sempurna. Jurnal Akuntansi, Ekonomi dan Manajemen Bs=isnis e-ISSN: 2548-9836, 5(2), 267-273.

Rahardja, U., Aini, Q., \& Hardini, M. (2018). Penerapan Software Akuntansi Online Sebagai Penunjang Pencatatan Laporan Keuangan. SISFOTENIKA, 8(2), 176-187.

Waspodo, L. (2014). Pengaruh Implementasi Software Akuntansi Terhadap Kinerja Pegawai: Perceived Enjoyment dan Computer Playfulness Sebagai Variabel Moderating. Jurnal Manajemen Bisnis, 5(2), 209-222. 